\title{
PENGARUH PERPUTARAN PERSEDIAAN, PERPUTARAN PIUTANG DAN MODAL INTELEKTUAL TERHADAP PROFITABILITAS PADA PERUSAHAAN MANUFAKTUR YANG TERDAFTAR DI BURSA EFEK INDONESIA (BEI) PERIODE 2014 - 2016
}

\author{
(Penelitian Empiris Pada Perusahaan Manufaktur Yang Terdaftar Di \\ Bursa Efek Indonesia Periode 2014 - 2016)
}

\author{
Nurainun Bangun, Susanto Salim dan Henryanto Wijaya \\ Fakultas Ekonomi Universitas Tarumanagara Jakarta
}

Email: inun66@yahoo.com; stsalim@yahoo.com; henryanto.wijaya@gmail.com

\begin{abstract}
This study aims to find out how (1) the simultaneous influence inventory turnover, receivable turnover, and intellectual capital on the profitability of manufacturing companies in the period 2014-2016, (2) the partial influence of influence inventory turnover, receivable turnover, and intellectual capital variables on the profitability of manufacturing companies in the period 2014-2016. This research uses purposive sampling in taking data. The data collected will be analyzed using multiple linear analysis. The result of this research is (1) there is significant influence from inventory turnover variable to profitability, (2) there is no significant influence from receivable turnover variable to profitability, (3) there is positive significant influence from value added capital employedvariable to profitability, (4) there is positive significant influence from value added human capital variable to profitability, (5) there is positive significant influence from structural capital value added variable to profitability, (6) there is a significant effect of inventory turnover, receivable turnover,value added capital employed, value added human capital, and from structural capital value addedon profitability simultaneously.
\end{abstract}

Keywords: inventory turnover, account receivable turnover, intellectual capital, profitability

\begin{abstract}
Abstrak: Tujuan penelitian untuk mengetahui bagaimana (1) pengaruh secara simultan dari perputaran persediaan, perputaran piutang, dan modal intelektual terhadap profitabilitas perusahaan manufaktur dalam periode 2014-2016, (2) pengaruh parsial dari variabel perputaran persediaan, perputaran piutang, dan modal intelektual terhadap profitabilitas perusahaan manufaktur dalam periode 2014-2016. Penelitian ini menggunakan purposive sampling dalam pengambilan data. Data yang telah dikumpulkan akan dianalisis dengan menggunakan analisis linear berganda. Hasil penelitian yang didapat dalam penelitian ini adalah (1) terdapat pengaruh yang signifikan dari variabel perputaran persediaan terhadap profitabilitas,(2) terdapat pengaruh negative tidak signifikan dari variabel perputaran piutang terhadap profitabilitasperusahaan (3) Terdapat pengaruh positif signifikan Value Added Capital Employed terhadap profitabilitas (ROA) perusahaan, (4)Terdapat pengaruh positif signifikan Value Added Human Capital terhadap profitabilitas (ROA) perusahaan(5)Terdapat pengaruh positif signifikan Structural Capital Value Added terhadap profitabilitas (ROA) perusahaan, (6) Terdapat pengaruh yang signifikan dari variabel Perputaran Persediaan, Perputaran Piutang, Value Added Capital Employed, Value Added Human Capital, dan Structural Capital Value Added Terhadap Profitabilitas $(R O A)$ perusahaan secara simultan atau bersamaan.
\end{abstract}


Kata Kunci: perputaran persediaan, perputaran piutang, modal intelektual, profitabilitas PENDAHULUAN

Setiap perusahaan memiliki visi dan misi yang sangat penting untuk mencapai sasaran dan tujuan perusahaan. Di antara banyaknya tujuan perusahaan, mendapatkan keuntungan yang maksimal merupakan salah satu tujuan utama yang harus dicapai oleh perusahaan demi pengembangan jangka pendek dan jangka panjang perusahaan. Kemampuan perusahaan dalam memperoleh laba sangat diperlukan untuk dapat dikatakan bahwa perusahaan mempunyai kinerja yang baik.

Profitabilitas adalah kemampuan perusahaan dalam memperoleh laba. Keefektifan perusahaan dalam menjalankan operasinya dapat ditunjukkan dengan profitabilitas yang tinggi, sebaliknya profitabilitas yang rendah menunjukkan bahwa perusahaan kurang efektif dalam menjalankan operasinya. Angka profitabilitas yang tinggi juga menunjukan bahwa perusahaan lebih siap untuk bertahan di masa yang akan datang karena menggambarkan bahwa perusahaan memiliki kemampuan manajerial yang baik dalam menjalankan keefektifan kinerja perusahaan untuk memperoleh laba yang maksimal.

Perhitungan profitabilitas perusahaan dapat dihitung menggunakan berbagai cara, dalam penelitian ini, perhitungan profitabilitas perusahaan dengan menggunakan Return on Asset. Variabel bebas dalam penelitian ini adalah perputaran persediaan, perputaran piutang, dan modal intelektual. Rasioyang dapat digunakan untuk mengukur profitabilitas adalah rasio perputaran persediaan. Rasio perputaran persediaan adalah pengukuran efisiensi dari pengelolaan barang yang akan diperjualbelikan.Semakin tinggi rasio ini menandakan cepatnya perputaran persediaan yang terjadi di dalam perusahaan dan juga pertanda bahwa perusahaan yang baik.

Rasio perputaran piutang dapat mengukur profitabilitas. Piutang merupakan merupakan komponen yang cukup penting untuk aktivitas ekonomi suatu perusahaan karenamerupakan aktiva lancar perusahaan yangbesar. Apabila perusahaan tersebut mampumengelola piutang dengan baik maka dapat menjalankan operasinya secara efektif dan efisien yang akan berpengaruh kedalam tingkat keuntungan perusahaan. (Lestarinigsih, 2015).

Modal intelektual merupakan aset tidak berwujud yang memiliki peran penting yang dapat dimanfaatkan secara efektif untuk meningkatkan keuntungan suatu perusahaan. Salim dan Karyawati (2013) menyatakan bahwa Intellectual Capital mencakup semua pengetahuan dan kemampuan perusahaan untuk menciptakan nilai tambah dan keunggulan kompetitif. Dari definisi di atas maka dapat disimpulkan bahwa modal intelektual adalah aset tidak berwujud yang bernilai yang dapat memberikan manfaat dan nilai lebih bagi perusahaan.

Berdasarkan hasil penelitan yang dilakukan oleh Utami dan Dewi (2016), menyatakan bahwa terdapat pengaruh signifikan variableinventory turnover terhadap profitabilitas. Hasil penelitian sama dengan hasil penelitian yang sama juga didapatkan oleh Naibaho dan Rahayu (2014). Namun penelitian oleh Sartika, Feranika dan Wahyudi (2015)mendapatkan hasil bahwa inventory turnovertidak memiliki pengaruh yang signifikan terhadap profitabilitas.

Berdasarkan hasil penelitian yang telah dilakukan oleh Utami dan Dewi (2016) menyatakan bahwa receivable turnover berpengaruh signifikan terhadap profitabilitas, penelitian tersebut didukungdengan penelitian yang telah dilakukan oleh Lestariningsih (2015) yaitu receivable turnover berpengaruh signifikan terhadap profitabilitas, 
namunpenelitian tersebut berbeda Diana dan Santoso (2016) yang memberikan pernyataan bahwa antara receivable turnover tidak memiliki pengaruh yang signifikan dengan profitabilitas.

Penelitian yang dilakukan oleh Sardo dan Serrasqueiro (2017) yang membagi 3 komponen intellectual capital menyatakan bahwa VAHU, VACA berpengaruh positif dan signifikan terhadap profitabilitas (ROA), dan STVA berpengaruh negatif dan signifikan terhadap profitabilitas (ROA). Namun, menurut Suhendah (2012) VAHU dan VACA tidak berpengaruh signifikan terhadap profitabilitas (ROA), dan STVA berpengaruh signifikan terhadap profitabilitas (ROA).

\section{KAJIAN TEORI}

Profitabilitas. Profitabilitas adalah kemampuan perusahaan dalam menghasilkan laba pada suatu waktu atau periode tertentu (Dewi \& Wirajaya, 2013). Pengukuran profitabilitas sangat diperlukan oleh perusahaan untuk mengetahui seberapa efektif kinerja yang dilakukan oleh suatu perusahaan. Angka profitabilitas yang tinggi menunjukkan bahwa perusahaan memiliki kinerja yang baik untuk menghasilkan laba (Novari \& Lestari, 2016).Tingkat profitabilitas perusahaan dapat diukur dengan rasio profitabilitas perusahaan. Menurut Kasmir (2012:196) rasio profitabilitas adalah rasio untuk menilai kemampuan perusahaan dalam mencari keuntungan. Salah satu cara untuk menghitung rasio profitabilitas adalah dengan menggunakan Return on Assets (ROA). Weygrandt, Kimmel, dan Kieso (2015) mengatakan bahwa "An overall measure of profitability is return on assets."

Berdasarkan definisi di atas dapat disimpulkan bahwa ukuran keseluruhan profitabilitas perusahaan dihitung menggunakan Return on Assets. Nilai Return on Assets yang semakin tinggi dapat menunjukkan tingkat efisiensi perusahaan yang tinggi dalam menggunakan asetnya untuk menghasilkan laba. Return on Assets dapat dihitung dengan membandingkan laba tahun berjalan dengan total aset.

Perputaran Persediaan. Rahma (2011) dalam Sari dan Budiasih (2014) mengatakan bahwa, persediaan merupakanbarang yang akan dijual kembali, baik diolah maupun tidak diolah dari perusahaan dan merupakan aset yang mengalami perputaran secara berkelanjutan. Fitri(2013) dalam Sari dan Budiasih (2014) menyatakaninventory turnover yang lambat menunjukkan semakin lama persediaan berada di perusahaan, sehingga dapat memperbesar biaya persediaan, dan akan menurunkan laba perusahaan.

Menurut Diana dan Santoso (2016), inventory turnovermenunjukan kemampuan dana yang ada dalam persediaan dapat berputar dalam suatu periode. Pengertian di atas disimpulkan menjadi perputaran persediaan perusahaan terkait dengan profitabilitas perusahaan. Dengan perumusan harga pokok penjualan di bandingkan dengan rata-rata persediaan perusahaan.

Perputaran Piutang.mMenurut Diana dan Santoso (2016) menyatakan bahwa,"account receivable turnovermerupakan kemampuan dana yang melalui penjualan yang ada dalam piutang berputar berapakali dalam suatu periode. Periode perputaran piutang bergantung pada kondisi pembayaran kreditnya, semakin lama suatu periode perputaran piutang maka semakin lama periode terikatnya dana dalam piutang. Apabila tingkat account receivable turnoversemakin besar maka dana yang diinvestasikan dalam piutang akan semakin kecil" 
Menurut Purnamasari dan Fitria (2015) mengatakan bahwa semakin singkat waktudebitur melakukan pelunasan piutang kepada perusahaan, maka semakin baik untuk kas perusahaan, sehingga kebutuhan kas akan modal kerja untuk membiayai aktiviatas operasi perusahaan dapat terpenuhi.

Modal Intelektual.Pengertiandari Intellectual Capital juga dikemukakan oleh Kartika dan Hartane (2013) yang menyatakan bahwa Intellectual Capital merupakan aset utama perusahaan selain aset fisik dan finansial. Intellectual Capital mecakup daya pikir karyawan, kemampuan mengelola organisasi dan menjalin hubungan dengan pihak luar.Pulic (2000) dalam Ulum (2013) mengembangkan pengukuran Intellectual Capital melalui nilai yang dimiliki. Metode VAIC ${ }^{\mathrm{TM}}$ didesain untuk menyajikan informasi tentang value creation efficiency dari aset berwujud (tangible assets) dan aset tidak berwujud (intangible assets) yang dimiliki perusahaan. 3 komponen utama dalam menghitung modal intelektual adalah physical capitalyang diukur dengan VACA, human capital yang diukur dengan VAHU, dan structural capitalyang diukur dengan STVA. Menurut Cahyani, Widiarti, dan Ferdiana (2015), Value added (VA)merupakan indikator objektif yang menunjukkan kemampuan perusahaan dalam menciptakan nilai (value creation). VA dihitung sebagai selisih antara output dan input. Outputs (OUT) mempresentasikan pendapatan/revenue dan mencakup seluruh produk dan jasa yang dijual di pasar. Inputs (IN) mencakup seluruh beban yang digunakan dalam memperoleh pendapatan/revenue. Hal yang terpenting dalam model ini adalah bahwa beban karyawan tidak termasuk dalam IN. Karena peran aktifnya dalam proses value creation, intellectual potential (yang dipresentasikan sebagai beban karyawan) tidak dihitung sebagai biaya (Ulum 2009 dalam Cahyani, Widiarti, dan Ferdiana, 2015).

VACA merupakan kemampuan perusahaan dalam mengelola sumber daya berupa capital asset yang apabila dikelola dengan baik akan meningkatkan kinerja keuangan perusahaan (Kartika dan Hatane, 2013). Value Added Capital Employed (VACA) dihitung dengan cara Value Added dibagi dengan jumlah ekuitas (capital employed). Value Added Human Capital (VAHU) merupakan salah satu pengukuran intellectual capital yang menunjukkan berapa banyak VA dapat dihasilkan dengan dana yang dikeluarkan untuk tenaga kerja. Hubungan antara VA dan Human Capital (HC) mengindikasikan kemampuan dari $\mathrm{HC}$ dalam menciptakan nilai di dalam perusahaan, dengan kata lain rasio ini menunjukkan kontribusi yang dibuat oleh setiap rupiah yang diinvestasikan dalam HC terhadap value VA perusahaan ((Ulum 2009 dalam Cahyani, Widiarti, dan Ferdiana, 2015). Value Added Human Capital (VAHU) dihitung dengan cara Value Added dibagi dengan beban karyawan (human capital).Structural Capital Value Added (STVA) mengukur jumlah structural capital yang dibutuhkan dalam menghasilkan satu rupiah dari VA dan merupakan indikasi atas keberhasilan SC dalam penciptaan nilai atau value creation. (Ulum 2009 dalam Cahyani, Widiarti, dan Ferdiana, 2015). Structural Capital Value Added (STVA) dihitung dengan cara Value Added dikurang beban karyawan (human capital) lalu dibagi dengan jumlah Value Added

Kerangka Pemikiran. Dari pembahasan sebelumnya, penelitian ini akan membahas mengenai pengaruh perputaran persediaan (ITO),perputaran piutang $(R T O)$, dan modal intelektual (VACA, VAHU, STVA)terhadap profitabilitas $(R O A)$. Variabel independen (bebas) dalam penelitian adalah pengaruh perputaran persediaan (ITO),perputaran piutang $(R T O)$, dan modal intelektual (VACA, VAHU, STVA). Dan yang menjadi variabel 
dependen (terikat) adalah profitabilitas (ROA). Maka gambaran dari kerangka pemikiran dari penelitian ini adalah sebagi berikut:

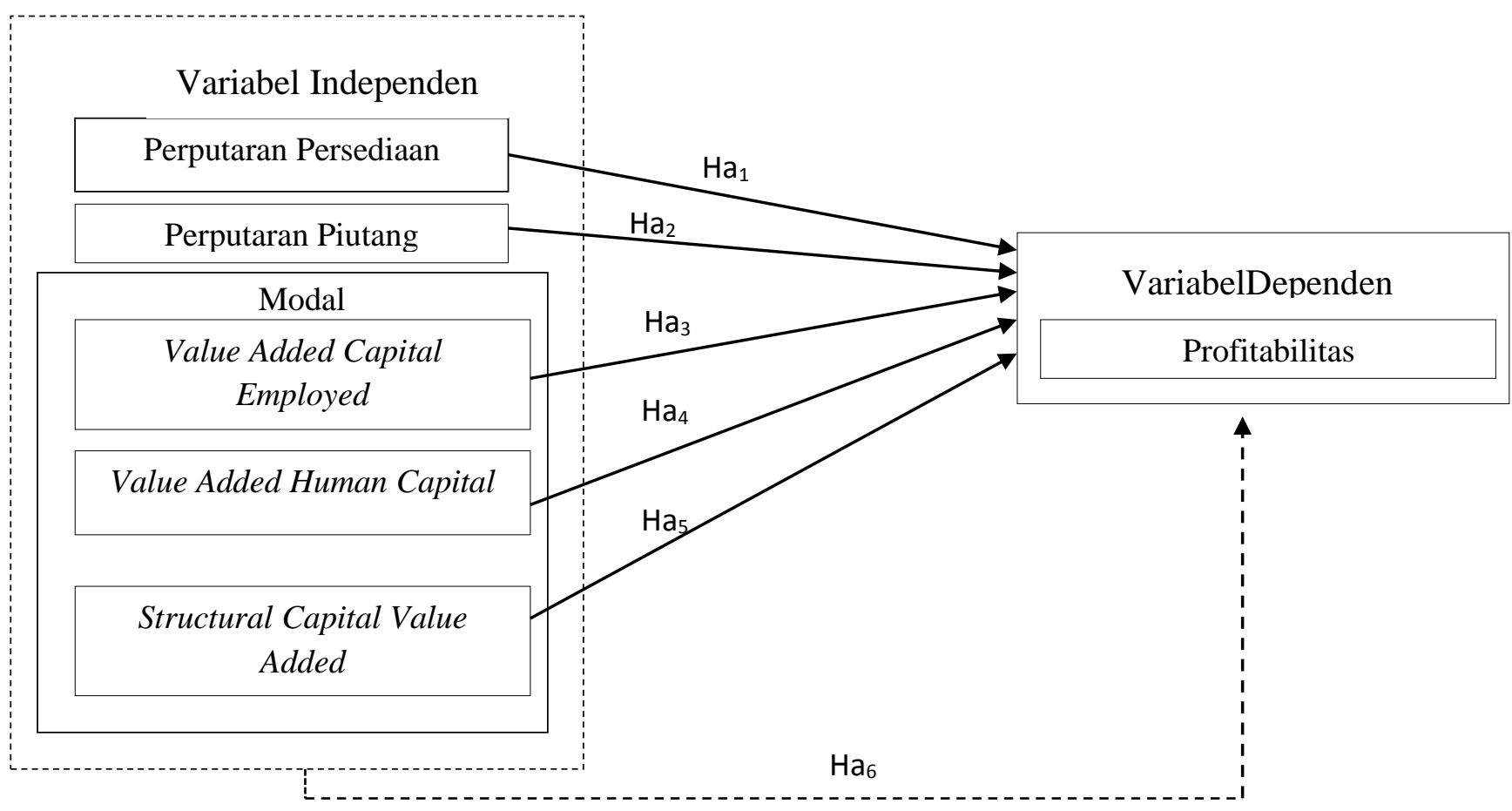

Gambar 1. Bagan Perumusan Hipotesis Penelitian

\section{Hipotesis. Pengaruh Perputaran Persediaanterhadap Profitabilitas.}

Horngren (2003:250) dalam Sartika, Feranika dan Wahyudi (2015) menyatakan bahwa, inventory turnover mengukur kecepatan rata-rata persediaan yang keluar dari perusahaan. Menurut Kasmir (2011:180) dalam Wijaya dan Tjun (2017)inventory turnoveradalahrasio yang digunakan untukmengukur berapa kali dana yang dada dalam persediaan (inventory) berputar suatuperiode.

Ha1:Inventory Turnoverberpengaruh negatif signifikan terhadap profitabilitas (ROA).

\section{Hipotesis. Pengaruh Perputaran Piutang terhadap Profitabilitas.}

Menurut Halim dan Sarwoko (2003) dalam Dewi, Suwendra,dan Yudiaatmaja (2016) menyatakan bahwa account receivable turnoveradalah suatu periode yang akan mneggambarkan berapa kali piutang yang ada sampai piutang tersebut ditagih.

$\mathrm{Ha}_{2}$ :Receivable turnoverberpengaruh negatif signifikan terhadap profitabilitas (ROA)

Hipotesis. Pengaruh Value Added Capital Employed terhadap Profitabilitas. VACA merupakan kemampuan perusahaan dalam mengelola sumber daya berupa capital asset yang apabila dikelola dengan baik akan meningkatkan kinerja keuangan perusahaan (Kartika dan Hatane, 2013).

Ha3: Value Added Capital Employedberpengaruh positif signifikan terhadap profitabilitas (ROA) perusahaan.

Hipotesis. Pengaruh Value Added Human Capital terhadap Profitabilitas. Hubungan antara VA dan Human Capital (HC) mengindikasikan kemampuan dari HC dalam 
menciptakan nilai di dalam perusahaan, dengan kata lain rasio ini menunjukkan kontribusi yang dibuat oleh setiap rupiah yang diinvestasikan dalam HC terhadap value VA perusahaan (Ulum 2009 dalam Cahyani, Widiarti, dan Ferdiana, 2015). Perusahaan dengan angka VAHU yang tinggi dinilai mampu meningkatkan profitabilitas perusahaan, karena keunggulan pengetahuan dan keterampilan karyawan dapat meningkatkan kinerja keuangan suatu perusahaan yang dapat memaksimalkan laba

Ha4: Value Added Human Capitalberpengaruh positif signifikan terhadap profitabilitas (ROA) perusahaan.

Hipotesis. Pengaruh Structural Capital Value Added terhadap Profitabilitas. Structural Capital Value Added (STVA) mengukur jumlah structural capital yang dibutuhkan dalam menghasilkan satu rupiah dari VA dan merupakan indikasi atas keberhasilan SC dalam penciptaan nilai atau value creation. (Ulum 2009 dalam Cahyani, Widiarti, dan Ferdiana, 2015). Perusahaan dengan angka STVA yang tinggi dinilai mampu meningkatkan profitabilitas perusahaan, karena Structural Capital merupakan sarana pendukung Human Capital dalam meningkatkan kinerja perusahaan.

Has: Structural Capital Value Added berpengaruh positif signifikan terhadap profitabilitas (ROA) perusahaan.

Hipotesis. Pengaruh Perputaran Persediaan, Perputaran Piutang, Value Added Capital Employed, Value Added Human Capital, dan Structural Capital Value Added Terhadap Profitabilitas.

Ha6: Pengaruh Perputaran Persediaan, Perputaran Piutang, Value Added Capital Employed, Value Added Human Capital, dan Structural Capital Value Addedberpengaruh signifikan terhadap profitabilitas perusahaan.

\section{METODE}

Desain Penelitian. Metode penelitian menggunakan metode penelitian kuantitatif yang mempunyai desain penelitian kausal. Penentuan desain dan metode penelitian ini adalah dengan bermaksud untuk menguji hipotesis penelitian. Untuk menguji pengaruh dari variabel independen penelitian terhadap variabel dependen penelitian baik secara pengujian pengaruh parsial maupun pengaruh secara simultan.

Populasi, Teknik Pemilihan Sampel, Ukuran Sampel. Yang menjadi populasi dalam penelitian ini adalah seluruh perusahaan manufaktur yang tercatat di Bursa Efek Indonesia (BEI) dalam periode 2014 - 2016. Pemilihan populasi ini adalah dengan alasan terdapat banyak perusahaan yang bergerak dibidang manufaktur sehingga dapat memenuhi kriteria sebagai data penelitian dari segi jumlah data.

Jumlah data perusahaan manufaktur sebanyak 144 perusahaan, dan yang memenuhi kriteria untuk penelitian sebanyak59 perusahaan pertahun. Dengan begitu jumlah data penelitian adalah sebanyak 177 data secara keseluruhannya. Penentuan kriteria dalam menyeleksi perusahaan yang akan menjadi data penelitian adalah merupakan teknik pemilihan sampel penelitian dengan metode purposive sampling. Ukutan sampel yang didapat setelah melakukan pengujian didapat data outlier sehingga data yang tersisa adalah sebanyak 165 data. 
Metode Analisis Data.Untuk melakukan analisis data penelitian, menggunakan bantuan software yang bernama SPSS versi 23.0. Yang mempunyai kegunaan untuk menganalisis data baik data parametric maupun non-parametrik yang dioperasikan dengan windows.

Pengujian Hipotesis. Untuk menguji hipotesispenelitian, menggunakan model pengujian persamaan regresi berganda. Dengan persamaan tersebut dapat diperoleh hasil bahwa apakah terdapat pengaruh yang signifikan dari Perputaran Persediaan (ITO), Perputaran Piutang (RTO),Value Added Capital Employed, Value Added Human Capital, dan Structural Capital Value Addedberpengaruh signifikan terhadap profitabilitas perusahaan. Persamaan regresi yang dimiliki penelitian ini adalah :

$Y=\alpha+\beta_{1} X_{1}+\beta_{2} X_{2}+\beta_{3} X_{3}+\beta_{4} X_{4}+\beta_{5} X_{5}+\varepsilon$

Keterangan: $\mathrm{Y}=$ Profitabilitas; $\alpha=$ Konstanta; $\beta_{1} \beta_{3}=$ Koefisien Regresi; $X_{1}=$ Inventory Turnover; $\mathrm{X}_{2}=$ Receivable Turnover $; \mathrm{X}_{3}=$ Value Added Capital Employed; $\mathrm{X}_{4}=$ Value Added Human Capital; $\mathrm{X}_{5}=$ Structural Capital Value Added; $\varepsilon=$ Error terms

Dalam pengujian hipotesis penelitian adalah dengan melakukan pengujian uji koefisen determinasi (R Square), uji statistik F dan juga uji statistik t. Pengujian koefisien determinasi adalah bertujian untuk mengukur seberapa jauh kemampuan dari model regresi dapat menjelaskan variabel dependen.

Uji statistik $\mathrm{F}$ adalah untuk menguji pengaruh keseluruh variabel independen dalam mempengaruhi variabel dependen penelitian secara simultan atau bersamaan. Uji statistik $t$ merupakan suatu pengujian yang digunakan untuk menguji pengaruh dari masing-masing variabel independen terhadap variabel dependen penelitian secara parsial atau individual.Dalam pengujian statistik $\mathrm{F}$ dan statistik t menggunakan tingkat kepercayaan sebesar 95\%. Jadi apabila dari hasil pengujian $\mathrm{F}$ dan $\mathrm{t}$ menghasilkan nilai sig $>0,05$, maka tidak terdapat pengaruh yang signifikan dari variabel independen terhadap veriabel dependen penelitian baik secara parsial maupun simultan.

\section{HASIL DAN PEMBAHASAN}

Subjek dalam penelitian adalah perusahaan manufaktur yang terdaftar di Bursa Efek Indonesia (BEI) selama periode 2014-2016. Dari total 144 perusahaan yang terdaftar, sampel yang memenuhi kriteria penelitian ini adalah sebanyak 59 perusahaan. Dan dari total data sebanyak 177 data, terdapat data outlier sehingga data yang digunakan peneliti untuk diobservasi dalam penelitian ini berjumlah 165 data.

Objek dari penelitian adalahPerputaran Persediaan (ITO), Perputaran Piutang (RTO),Value Added Capital Employed, Value Added Human Capital, dan Structural Capital Value Addedsebagai variabel independen dan variabel dependen penelitian ini adalah profitabilitas. Objek penelitian ini mempunyai data yang terdistribusi dengan tidak normal sehingga peneliti menggunakan bantuan pengolahan data dengan metode transformasi data dengan bentuk SQRT(x). Setelah itu dilakukan outlier data, untuk mendeteksi adanya data outlier.

Uji Asumsi Klasik. Uji Normalitas. Pengujian normalitas adalah untuk memperoleh gambaran mengenai data tersebut telah terdistribusi dengan normal atau tidak. Dalam penelitian ini menggunakan pengujian normalitas dengan Kolmogorov-Smirnov 
Tabel 1. Hasil Uji Normalitas dengan Kolmogorov-Smirnov One-Sample Kolmogorov-Smirnov Test

\begin{tabular}{llr}
\hline & & $\begin{array}{r}\text { Unstandardized } \\
\text { Residual }\end{array}$ \\
\hline $\mathrm{N}$ Normal Parameters ${ }^{\mathrm{a}, \mathrm{b}}$ & Mean & 165 \\
& Std. Deviation & .0000000 \\
Most Extreme & Absolute & .04173618 \\
Differences & Positive & .052 \\
& Negative & .052 \\
Test Statistic & &. .039 \\
Asymp. Sig. (2-tailed) & .052 \\
\hline a. Test distribution is Normal. \\
b. Calculated from data. \\
$\begin{array}{l}\text { c. Lilliefors Significance Correction. } \\
\text { d. This is a lower bound of the true significance. }\end{array}$ \\
\hline
\end{tabular}

Dari hasil pengujian tersebut, maka dapat disimpulkan bahwa data penelitian terdistribusi dengan normal. Dari pengujian dengan Kolmogorov-Smirnov didapatkan hasil Asymp. Sig. (2-tailed) dengan nilai 0,200 >0,05. Maka data pengujian terdistribusi dengan normal.

Uji Multikolinearitas. Uji multikolinearitas adalah bertujian untuk menguji apakah terdapat korelasi dari setiap variabel independen penelitian. Data penelitian yang baik adalah yang bebas daeri adanya multikolinearitas.

Tabel 2. Hasil Uji Multikolinearitas

\begin{tabular}{|c|c|c|c|c|c|c|c|c|}
\hline \multicolumn{9}{|c|}{ Coefficients $^{\mathrm{a}}$} \\
\hline \multirow{2}{*}{\multicolumn{2}{|c|}{ Model }} & \multicolumn{2}{|c|}{$\begin{array}{l}\text { Unstandardized } \\
\text { Coefficients }\end{array}$} & \multirow{2}{*}{$\begin{array}{l}\text { Standardized } \\
\text { Coefficients } \\
\text { Beta }\end{array}$} & \multirow[b]{2}{*}{$\mathrm{t}$} & \multirow[b]{2}{*}{ Sig. } & \multicolumn{2}{|c|}{$\begin{array}{l}\text { Collinearity } \\
\text { Statistics }\end{array}$} \\
\hline & & $\mathrm{B}$ & Std. Error & & & & Tolerance & VIF \\
\hline 1 & (Constant) & -.268 & .020 & & -13.652 & .000 & & \\
\hline & S_ITO & -.020 & .005 & -.111 & -4.015 & .000 & .851 & 1.175 \\
\hline & S_RTO & -.004 & .004 & -.033 & -1.166 & .245 & .806 & 1.241 \\
\hline & S_VACA & .395 & .023 & .446 & 17.159 & .000 & .964 & 1.037 \\
\hline & S_VAHU & .127 & .020 & .334 & 6.336 & .000 & .235 & 4.259 \\
\hline & S_STVA & .346 & .036 & .526 & 9.571 & .000 & .216 & 4.636 \\
\hline
\end{tabular}

a. Dependent Variable: S_ROA

Dikatakan bebas dari multikolinearitas adalah apabila nilaitolerancevariabel independen lebih besar dari 0,10. S_ITO sebesar 0,851>0,10, S_RTO sebesar 0,806> 0,10,S_VACA sebesar 0,964>0,10, S_VAHU sebesar 0,235 > 0,10, dan S_STVA sebesar $0,216>0,10$ nilai tolerance dari seluruh variabel independen lebih besar dari 0,10 . Dan nilai VIF harus kurang dari 10,S_ITO sebesar 1,175 < 10, S_RTO sebesar 1,241 < 10,S_VACA sebesar 1,037<10, S_VAHU sebesar 4,259<10, dan S_STVA sebesar 4,636 
<10. Seluruh nilai VIF variabel independen kurang dari 10. Dengan demikian data penelitian lulus dari pengujian multikolinearitas.

Uji Autokorelasi. Pengujian autokorelasi adalah pengujian untuk menguji mengenai kesalahan pengganggu dalam model regresi berganda. Data yang baik adalah data yang tidak terdapat autokorelasi di dalamnya.

Tabel 3. Hasil Uji Autokorelasi dengan Durbin-Watson

\begin{tabular}{rrrrrr}
\multicolumn{7}{c}{ Model Summary $^{\mathbf{b}}$} \\
\hline Model & $\mathrm{R}$ & R Square & $\begin{array}{c}\text { Adjusted R } \\
\text { Square }\end{array}$ & $\begin{array}{l}\text { Std. Error of } \\
\text { the Estimate }\end{array}$ & \multicolumn{1}{c}{$\begin{array}{l}\text { Durbin- } \\
\text { Watson }\end{array}$} \\
\hline 1 & $.947^{\mathrm{a}}$ & .896 & .893 & .04239 & 2.006 \\
\hline
\end{tabular}

a. Predictors: (Constant), S_STVA, S_VACA, S_ITO, S_RTO, S_VAHU

b. Dependent Variable: S_ROA

Dari hasil pengujian di dapatkan hasil Durbin-Watson sebesar 2,006. Dengan 165 sampel dan variabel independen sebanyak 5variabel, maka nilai $\mathrm{dl}=1,6834$, niali $\mathrm{du}=1,8082$. Syarat dinyatakan lulus uji autokerelasi adalah $\mathrm{du}<\mathrm{d}<4-\mathrm{du}$, yang jika dirumuskan $1,8082<2,006<2,1918$. Berarti disimpulkan tidak terdapat autokorelasi dalam data penelitian.

Uji Heteroskedastisitas. Pengujian heteroskedastisitas merupakan suatu pengujian untuk mengetauhi apakah variance residual antara pengamatan yang satu dengan lainnya tetap atau tidak, Data yang baik adalah data yang bebas dari heteroskedastisitas atau data homoskedastisitas.Pengujian heteroskedastisitas dalam penelitian ini menggunakan uji Spearman.

Tabel 4. Hasil Uji Heteroskedastisitas dengan Uji Spearman

\begin{tabular}{|c|c|c|c|c|c|c|c|c|}
\hline \multicolumn{9}{|c|}{ Correlations } \\
\hline & & & S_ITO & S_RTO & S_VACA & S_VAHU & S_STVA & $\begin{array}{l}\text { Unstandardiz } \\
\text { ed Residual }\end{array}$ \\
\hline \multirow[t]{15}{*}{$\begin{array}{l}\text { Spearma } \\
\text { n's rho }\end{array}$} & \multirow[t]{3}{*}{ S_ITO } & $\begin{array}{l}\text { Correlation } \\
\text { Coefficient }\end{array}$ & 1.000 & . 093 & -.026 & $.322^{* *}$ & $.322^{* *}$ & -.083 \\
\hline & & Sig. (2-tailed) & & .233 & .744 & .000 & .000 & .289 \\
\hline & & $\mathrm{N}$ & 165 & 165 & 165 & 165 & 165 & 165 \\
\hline & \multirow[t]{3}{*}{ S_RTO } & $\begin{array}{l}\text { Correlation } \\
\text { Coefficient }\end{array}$ & .093 & 1.000 & .128 & $.366^{* *}$ & $.366^{* *}$ & .031 \\
\hline & & Sig. (2-tailed) & .233 & & .102 & .000 & .000 & .696 \\
\hline & & $\mathrm{N}$ & 165 & 165 & 165 & 165 & 165 & 165 \\
\hline & \multirow[t]{3}{*}{ S_VACA } & $\begin{array}{l}\text { Correlation } \\
\text { Coefficient }\end{array}$ & -.026 & . 128 & 1.000 & .026 & .026 & . 104 \\
\hline & & Sig. (2-tailed) & .744 & .102 & & .736 & .736 & .184 \\
\hline & & $\mathrm{N}$ & 165 & 165 & 165 & 165 & 165 & 165 \\
\hline & \multirow[t]{3}{*}{ S_VAHU } & $\begin{array}{l}\text { Correlation } \\
\text { Coefficient }\end{array}$ & $.322^{* *}$ & $.366^{* *}$ & .026 & 1.000 & $1.000^{* *}$ & .010 \\
\hline & & Sig. (2-tailed) & .000 & . 000 & .736 & & & .902 \\
\hline & & $\mathrm{N}$ & 165 & 165 & 165 & 165 & 165 & 165 \\
\hline & \multirow[t]{3}{*}{ S_STVA } & $\begin{array}{l}\text { Correlation } \\
\text { Coefficient }\end{array}$ & $.322^{* *}$ & $.366^{* *}$ & .026 & $1.000^{* *}$ & 1.000 & .010 \\
\hline & & Sig. (2-tailed) & .000 & .000 & .736 & & & .902 \\
\hline & & $\mathrm{N}$ & 165 & 165 & 165 & 165 & 165 & 165 \\
\hline
\end{tabular}




\begin{tabular}{|c|c|c|c|c|c|c|c|}
\hline $\begin{array}{l}\text { Unstanda } \\
\text { rdized }\end{array}$ & $\begin{array}{l}\text { Correlation } \\
\text { Coefficient }\end{array}$ & -.083 & .031 & .104 & .010 & .010 & 1.000 \\
\hline Residual & $\begin{array}{l}\text { Sig. (2-tailed) } \\
\mathrm{N}\end{array}$ & $\begin{array}{l}.289 \\
165\end{array}$ & $\begin{array}{l}.696 \\
165\end{array}$ & $\begin{array}{l}.184 \\
165\end{array}$ & $\begin{array}{l}.902 \\
165\end{array}$ & $\begin{array}{l}.902 \\
165\end{array}$ & 165 \\
\hline
\end{tabular}

Dalam pengujian heteroskedastisitas di atas, data terbukti merupakan data homoskedastisitas dari heteroskedastisitas dengan spearman yang menunjukkan nilai Sig. (2-tailed) pada baris paling atas dengan nilai sig. S_ITO sebesar 0,289>0,05, nilai S_RTO sebesar 0,696>0,05, nilai S_VACA sebesar 0,184>0,05, nilai S_VAHU sebesar 0,902 > 0,05, dan nilai S_STVA sebesar 0,902 > 0,05. Seluruh variabel independen lulus dari uji heteroskedastisitas.

\section{Hasil Analisis Data.}

Tabel 5. Hasil Uji Analisis Regresi Berganda Coefficients $^{\mathrm{a}}$

\begin{tabular}{|c|c|c|c|c|c|c|}
\hline \multirow[b]{2}{*}{ Model } & & \multicolumn{2}{|c|}{ Unstandardized Coefficients } & $\begin{array}{l}\text { Standardized } \\
\text { Coefficients }\end{array}$ & \multirow[b]{2}{*}{$\mathrm{t}$} & \multirow[b]{2}{*}{ Sig. } \\
\hline & & $\mathrm{B}$ & Std. Error & Beta & & \\
\hline 1 & (Constant) & -.268 & .020 & & -13.652 & .000 \\
\hline & S_ITO & -.020 & .005 & -.111 & -4.015 & .000 \\
\hline & S_RTO & -.004 & .004 & -.033 & -1.166 & .245 \\
\hline & S_VACA & .395 & .023 & .446 & 17.159 & .000 \\
\hline & S_VAHU & 127 & .020 & .334 & 6.336 & .000 \\
\hline & S_STVA & .346 & .036 & .526 & 9.571 & .000 \\
\hline
\end{tabular}

a. Dependent Variable: S_ROA

Dengan berdasarkan tabel di atas, bentuk persamaan regresi penelitian adalah sebagai berikut:

$$
Y=-0,268-0,020 X_{1}-0,004 X_{2}+0,395 X_{3}+0,127 X_{4}+0,346 X_{5}+\varepsilon
$$

Keterangan:

$\alpha=-0,268$ artinya jika Inventory Turnover (X1), Receivable Turnover (X2), Value Added Capital Employed (X3), Value Added Human Capital (X4), dan Structural Capital Value Added (X5) masing-masing diabaikan, maka profitabilitas (Y) bernilai $-0,268$

$\beta_{1}=-0,020$ artinya setiap peningkatan satu satuan Inventory Turnover (X1) akan menurunkanprofitabilitas (Y) sebesar -0.020 dengan asumsi variabel independen lainnya tetap. Karena koefisien yang dihasilkan negatif, berarti terdapat hubungan negatif pada variabel perputaran persediaan (X1) dan profitabilitas (Y).

$\beta_{2}=$-0,004artinya setiap peningkatan satu satuan Receivable Turnover (X2) akan menurunkan profitabilitas (Y) sebesar -0.0040 dengan asumsi variabel independen lainnya tetap. Karena koefisien yang dihasilkan negatif, berarti terdapat hubungan negatif pada variabel perputaran piutang (X2) dan profitabilitas (Y).

$\beta_{3}=0,395$ artinya setiap peningkatan satu satuan Value Added Capital Employed (X3) akan meningkatkan profitabilitas (Y) sebesar 0,395dengan asumsi variabel independen lainnya bernilai tetap. Karena koefisien menghasilkan nilai positif, berarti terdapat hubungan positif pada Value Added Capital Employed(X3) terhadapprofitabilitas (Y). 
$\beta_{4}=0,127$ artinya setiap peningkatan satu satuan Value Added Human Capital (X4) akan meningkatkan profitabilitas (Y) sebesar 0,127dengan asumsi variabel independen lainnya bernilai tetap. Karena koefisien menghasilkan nilai positif, berarti terdapat hubungan positif pada Value Added Human Capital (X4) terhadapprofitabilitas (Y).

$\beta_{5}=0,346$ artinya setiap peningkatan satu satuan Structural Capital Value Added (X5) akan meningkatkan profitabilitas (Y) sebesar 0,346dengan asumsi variabel independen lainnya bernilai tetap. Karena koefisien menghasilkan nilai positif, berarti terdapat hubungan positif pada Structural Capital Value Added (X5) terhadapprofitabilitas (Y).

Koefisien Determinasi (R Square). Koefisien determinasi merupakan pengujian untuk mengukur seberapa kemampuan model regresi penelitian dapat menjelaskan variasi dependen penelitian.

Tabel 6. Hasil Uji Koefisien Determinasi

\begin{tabular}{lrrrr}
\hline \multicolumn{5}{c}{ Model Summary $^{\mathbf{b}}$} \\
\hline Model & R & R Square & Adjusted R Square & Std. Error of the Estimate \\
\hline 1 & $.947^{\mathrm{a}}$ & .896 & .893 & .04239 \\
\hline
\end{tabular}

a. Predictors: (Constant), S_STVA, S_VACA, S_ITO, S_RTO, S_VAHU

b. Dependent Variable: S_ROA

Dari Tabel dapat disimpulkan bahwa variabel independen menjelaskan 89,3\% dari variabel dependen sisanya sebanyak $10,7 \%$ dijelaskan oleh variabel lain diluar yang digunakan dalam penelitian ini.

Uji Statistik t. Uji statistik $t$ merupakan pengujian untuk menguji pengaruh masingmasing variabel independen terhadap variabel dependen penelitian secara parsial atau individual.

Tabel 7. Tabel Hasil Uji Statistik t

\begin{tabular}{|c|c|c|c|c|c|c|}
\hline \multicolumn{7}{|c|}{ Coefficients $^{\mathrm{a}}$} \\
\hline \multirow[b]{2}{*}{ Model } & & \multicolumn{2}{|c|}{ Unstandardized Coefficients } & $\begin{array}{l}\text { Standardized } \\
\text { Coefficients }\end{array}$ & \multirow[b]{2}{*}{$\mathrm{t}$} & \multirow[b]{2}{*}{ Sig. } \\
\hline & & $\mathrm{B}$ & Std. Error & Beta & & \\
\hline 1 & (Constant) & -.268 & .020 & & -13.652 & .000 \\
\hline & S_ITO & -.020 & .005 & -.111 & -4.015 & .000 \\
\hline & S_RTO & -.004 & .004 & -.033 & -1.166 & .245 \\
\hline & S_VACA & .395 & .023 & .446 & 17.159 & .000 \\
\hline & S_VAHU & .127 & .020 & .334 & 6.336 & .000 \\
\hline & S_STVA & .346 & .036 & .526 & 9.571 & .000 \\
\hline
\end{tabular}

a. Dependent Variable: S_ROA

Uji Statistik F. Uji statistik F adalah untuk menguji pengaruh keseluruh variabel independen dalam mempengaruhi variabel dependen penelitian secara simultan atau bersamaan.

Tabel 8. Tabel Hasil Uji Statistik F

\begin{tabular}{|c|c|c|c|c|c|}
\hline \multicolumn{6}{|c|}{ ANOVA $^{\mathrm{a}}$} \\
\hline Model & Sum of Squares & $\mathrm{df}$ & Mean Square & $\mathrm{F}$ & Sig. \\
\hline Regression & 2.468 & 5 & .494 & 274.709 & $.000^{\mathrm{b}}$ \\
\hline
\end{tabular}




\begin{tabular}{lrrr} 
Residual & .286 & 159 & .002 \\
Total & 2.754 & 164 & \\
\hline
\end{tabular}

a. Dependent Variable: S_ROA

b. Predictors: (Constant), S_STVA, S_VACA, S_ITO, S_RTO, S_VAHU

Pembahasan. Pengaruh Perputaran Persediaan terhadap Profitabilitas. Dari pengujian pada tabel t didapat hasil $0,000<0,05$, yang berarti bahwa nilai signifikan yang diperoleh dari uji t lebih kecil dari pada nilai signifikan yang digunakan dalam penelitian sehingga Ho ditolak dan Ha diterima. Maka terdapat pengaruh negatif dan signifikan antar variabel Inventory Turnoverterhadap profitabilitas. Hasil ini didukung oleh penelitian sebelumnya, Wijaya dan Tjun (2017), yang menyatakan terdapat pengaruh negatif signifikan antara Inventory Turnover terhadap profitabilitas. Hasil yang berbeda diperoleh dari peneliti sebelumnya, dari Sartika, Veranika dan Wahyudi (2015), yang menyatakan bahwa tidak terdapat pengaruh signifikan antara Inventory Turnover terhadap profitabilitas perusahaan.

Pengaruh Perputaran Piutang terhadap Profitabilitas. Dari pengujian pada tabel $\mathrm{t}$ didapat hasil $0,245>0,05$, yang berarti bahwa nilai signifikan yang diperoleh dari uji $\mathrm{t}$ lebih besar dari pada nilai signifikan yang digunakan dalam penelitian sehingga Ho diterima dan Ha ditolak. Maka terdapat pengaruh negatif dan tidak signifikan antar variabel Receivable Turnoverterhadap profitabilitas. Hasil tersebut sejalan dengan penelitian yang dilakukan oleh Penelitian sebelumnya yang telah dilakukan oleh Diana dan Santoso (2016) yang menyatakan bahwa Receivable Turnovertidak memiliki pengaruh yang signifikan dengan profitabilitas. Tetapi berbeda dengan penelitian yang telah dilakukan oleh Utami dan Dewi (2016) dan Lestariningsih (2015) yang menyatakanInventory Turnover berpengaruh signifikan dan positif terhadap profitabilitas (ROA).

Pengaruh Value Added Capital Employed terhadap Profitabilitas. Berdasarkan hasil yang pengujian yang diperoleh dilihat pada tabel $t$, nilai $t$ hitung yang diperoleh adalah sebesar 6,336 dengan tingkat signifikan sebesar 0,000. Karena 0,000<0,05 maka hasil pengujian menujukkan bahwa hasil signifikan lebih kecil dari tingkat signifikan penelitian. Disimpulkan bahwaterdapat pengaruh positif dan signifikan antara Value Added Human Capitalterhadap profitabilitas (ROA) perusahaan.

Hasil penelitian ini sejalan dengan penelitian yang dilakukan olehSardo dan Serrasqueiro (2017) yang menyatakan bahwa VACA memiliki pengaruh yang positif dan signifikan terhadap ROA. Namun hasil penelitian ini tidak konsisten dengan penelitian yang dilakukan oleh Suhendah (2012) yang menyatakan bahwa VACA tidakmemiliki pengaruh yang signifikan terhadap profitabilitas perusahaan (ROA).

Pengaruh Value Added Human Capital terhadap Profitabilitas. Berdasarkan hasil yang pengujian yang diperoleh dilihat pada tabel $t$, nilai t hitung yang diperoleh adalah sebesar 17,159 dengan tingkat signifikan sebesar 0,000 . Karena $0,000<0,05$ maka hasil pengujian menujukkan bahwa hasil signifikan lebih kecil dari tingkat signifikan penelitian. Disimpulkan bahwa terdapat pengaruh positif dan signifikan antara Value Added Capital Employedterhadap profitabilitas (ROA) perusahaan.

Hasil penelitian ini sejalan dengan penelitian yang dilakukan olehSardo dan Serrasqueiro (2017) yang menyatakan bahwa VAHU memiliki pengaruh yang positif dan 
signifikan terhadap ROA. Namun hasil penelitian ini tidak konsisten dengan penelitian yang dilakukan oleh Suhendah (2012) yang menyatakan bahwa VAHU tidakmemiliki pengaruh yang signifikan terhadap ROA.

Pengaruh Structural Capital Value Added terhadap Profitabilitas. Berdasarkan hasil yang pengujian yang diperoleh dilihat pada tabel $t$, nilai t hitung yang diperoleh adalah sebesar 9,571 dengan tingkat signifikan sebesar 0,000. Karena $0,000<0,05$ maka hasil pengujian menujukkan bahwa hasil signifikan lebih kecil dari tingkat signifikan penelitian. Disimpulkan bahwa terdapat pengaruh positif dan signifikan antara Structural Capital Value Addedterhadap profitabilitas (ROA) perusahaan.

Hasil penelitian ini sejalan dengan penelitian yang dilakukan olehSuhendah (2012) yang menyatakan bahwa STVA memiliki pengaruh yang positif dan signifikan terhadap ROA. Namun hasil penelitian ini tidak konsisten dengan penelitian yang dilakukan olehSardo dan Serrasqueiro (2017) yang menyatakan bahwa STVAmemiliki pengaruh yang negatif dan signifikan terhadap ROA.

Pengaruh Perputaran Persediaan, Perputaran Piutang, Value Added Capital Employed, Value Added Human Capital, dan Structural Capital Value Added Terhadap Profitabilitas. Dari hasil uji F pada tabel diatas dapat dilihat nilai signifikansi yang dihasilkan sebesar 0,000 lebih kecil dari 0,05 sehingga $\mathrm{Ho}_{1}$ ditolak dan $\mathrm{Ha}_{1}$ diterima. Artinya hasil tersebut menunjukkan bahwa variabel independen dalam penelitian ini yaitu Perputaran Persediaan, Perputaran Piutang, Value Added Capital Employed, Value Added Human Capital, dan Structural Capital Value Addedsecara simultan atau secara bersamasama memiliki pengaruh yang signifikan terhadap variabel dependen (ROA).

\section{PENUTUP}

Simpulan. Dari pengujian yang telah dilakukan, didapatkan hasil : (1) Terdapat pengaruh negatif dan signifikan antar variabel perputaran persediaan (Inventory Turnover) terhadap profitabilitas $(R O A),(2)$ Terdapat pengaruh negative tidak signifikan antara perputaran persediaan $(R T O)$ terhadap profitabilitas $(R O A)$ perusahaan (3) Terdapat pengaruh positif signifikan Value Added Capital Employed terhadap profitabilitas (ROA) perusahaan, (4)Terdapat pengaruh positif signifikan Value Added Human Capital terhadap profitabilitas (ROA) perusahaan(5)Terdapat pengaruh positif signifikan Structural Capital Value Added terhadap profitabilitas (ROA) perusahaan, (6)Terdapat pengaruh yang signifikan dari variabel Perputaran Persediaan, Perputaran Piutang, Value Added Capital Employed, Value Added Human Capital, dan Structural Capital Value Added Terhadap Profitabilitas(ROA) perusahaan secara simultan atau bersamaan.

Keterbatasan dan Saran. Keterbatasan dari penelitian:(1)Penelitian ini hanya meneliti 3 variabel independen yaitu, perputaran persediaan, perputaran piutang, modal intelektual dan satu variabel dependen yaitu profitabilitas, (2)Perusahaan yang diobservasi hanya perusahaan yang membuat laporan keuangan menggunakan mata uang rupiah, (3)Penelitian yang dilakukan hanya meneliti perusahaan manufaktur yang terdaftar di BEI, (4) Sampel yang digunakan dalam penelitian hanya pada periode 2014-2016. Saran yang diberikan ialah: (1) Menambah variabel dalam penelitian baik variabel independen maupun pada variabel dependen, (2) Melakukan penelitian tidak hanya berdasarkan perusahaan yang menggunakan mata uang rupiah saja tetapi juga meneliti perusahan yang 
menggunakan mata uang asing., (3)Menambah sampel dalam penelitian dengan tidak hanya meneliti satu sektor perusahaan, (4) Memperpanjang periode penelitian atau periode pengamatan

\section{DAFTAR RUJUKAN}

Cahyani, R. I., Widiarti, T. S., \& Ferdiana, J. L. (2015). "Pengaruh Intellectual Terhadap Profitabilitas pada Perusahaan Manufaktur yang Terdaftar Capital Efek Indonesia". Jurnal Riset Akuntansi dan Perpajakan, 2(1), 1-18.

di Bursa

Diana, Putri Ayu \& Santoso, Bambang Hadi (2016). "Pengaruh Perputaran Kas, Piutang, Persediaan Terhadap Profitabilitas Pada Perusahaan Semen Di BEI". Jurnal Ilmu dan Riset Manajemen, 5(3), 1-18.

Kartika, M.\& Hatane, S. E. (2013). "Pengaruh Intellectual Capital Terhadap Profitabilitas Perusahaan Perbankan yang Terdaftar di Bursa Efek Indonesia pada Tahun 2007- 2011". Business Accounting Review, 1(2), 14-25.

Kasmir.(2012). Analisis Laporan Keuangan. Jakarta: PT. Raja Grafindo Persada.

Lestariningsih, Marsudi (2015). "Pengaruh Perputaran Modal Kerja, Perputaran Piutang, Perputaran Persediaan Terhadap Profitabilitas Perusahaan Manufaktur". Jurnal Ilmu Dan Riset Managemen, 4(4), 1-15.

Naibaho, Erik Pebrin \& Rahayu, Sri (2014). "Pengaruh Perputaran Piutang Dan Perputaran Persediaan Terhadap Profitabilitas (Studi Empiris Perusahaan Makanan Dan Minuman Yang Terdaftar Di BEI Tahun 2008-2012)". e-Proceeding of Management, 1(3), 279-290.

Novari, P. M. \& Lestari, P. V. (2016). "Pengaruh Ukuran Perusahaan, Leverage, dan Profitabilitas Terhadap Nilai Perusahaan pada Sektor Properti dan Real Estate". E-Jurnal Manajemen Unud, 5(9), 5671-5694.

Salim, S. M. \& Karyawati, G. (2013). "Pengaruh Modal Intelektual Terhadap Kinerja Keuangan". Journal of Business and Entrepreneurship, 1(2), 74-91.

Sardo, F. \& Serrasqueiro, Z. (2017). "A European Empirical Study of the Relationship Between Firms' Intellectual Capital, Financial Performance and Market Value”. Journal of Intellectual Capital, 18(4), 771-788.

Sari, Ni Made Vironika \& Budiasih, I G.A.N (2014). "Pengaruh Debt To Equity Ratio, Firm Size, Inventory Turnover Dan Assets Turnover Pada Profitabilitas". E-Jurnal Akuntansi Universitas Udayana, 261-273.

Sartika, Milda Unik, Feranika, Nungky Viana, \& Wahyudi, Koko Denik (2015). "Rasio Aktivitas Yang Mempengaruhi Profitabilitas Perusahaan Pada Sektor Otomotif Yang Terdaftar Di Bursa Efek Indonesia”. Majalah Ilmiah “DIAN ILMU”, 15(1), 75-89.

Ulum, I. (2013). "Model Pengukuran Kinerja Intellectual Capital dengan IB-VAIC di Perbankan Syariah". Jurnal Penelitian Sosial Keagamaan, 7(1), 185-206.

Utami, Made Sri \& Dewi S, Made Rusmala (2016). "Pengaruh Manajemen Modal Kerja Terhadap Profitabilitas Perusahaan Manufaktur Yang Terdaftar Di Bursa Efek Indonesia". E-Jurnal Manajemen Unud, 5(6), 3476- 3503.

Wijaya, Linda Vania \& Tjun, Lauw Tjun (2017). "Pengaruh Cash Turnover, Receivable Turnover, dan Inventory Turnover Terhadap Return On Asset Perusahaan Sektor Makanan dan Minuman yang Terdaftar di Bursa Efek Indonesia Periode 2013 2015”. Jurnal Akuntansi, 9(1), 74-82. 
Wirajaya, A. \& Dewi, A. S. M. (2013). "Pengaruh Struktur Modal, Profitabilitas dan Ukuran Perusahaan pada Nilai Perusahaan”. E-Jurnal Akuntansi Universitas Udayana, 4(2), 358-372.

Weygrandt, J. J., Kimmel, P. D., \& Kieso, D. E. (2015). Financial Accounting: $\quad$ IFRS 3rd Edition. Amerika Serikat: John Wiley \& Sons, Inc. 